\section{ANNUAL CHANGES OF BEACH PROFILE AND NEARSHORE SEDIMENT DISTRIBUTION OFF DUNGUN-KEMAMAN,TERENGGANU, MALAYSIA}

Rosnan Yaacoba, Hasrizal Shaaria,b*, Noraisyah Saponb, Mohammad Fadhli Ahmadc, Effi Helmi Arifina, Razak Zakariyaa, Mohd Lokman Hussainb

aSchool of Marine and Environmental Science, Universiti Malaysia Terengganu, 21030, Kuala Terengganu, Terengganu, Malaysia bInstitute of Oceanography and Environment, Universiti Malaysia Terengganu, 21030, Kuala Terengganu, Terengganu, Malaysia cSchool of Ocean Engineering, Universiti Malaysia Terengganu, 21030, Kuala Terengganu, Terengganu, Malaysia
Article history

Received

11 December 2017

Received in revised form

9 March 2018

Accepted

30 March 2018

Published online

1 August 2018

*Corresponding author riz@umt.edu.my

\section{Graphical abstract}

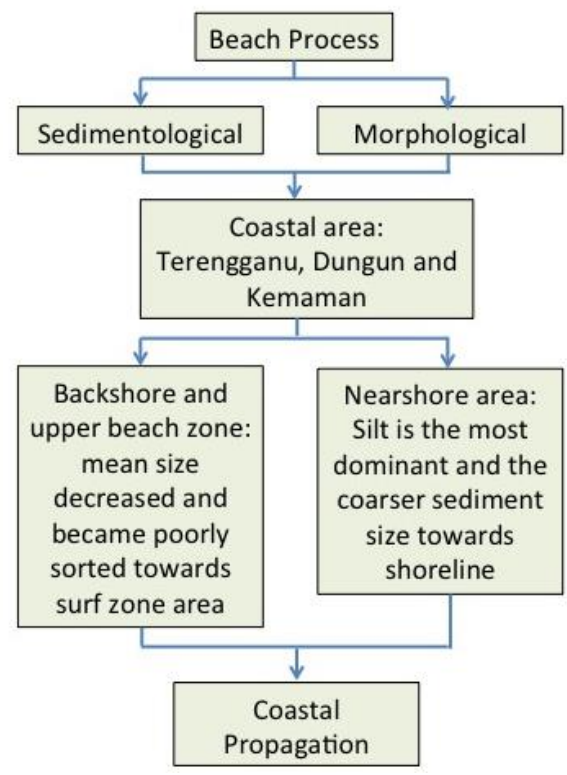

\begin{abstract}
A proper understanding of beach processes must include the adjacent shallow marine waters or nearshore environment. This paper focused on the sedimentological and morphological investigation of Terengganu coastal area stretch lies between Dungun and Kemaman. The study area comprised five beaches and 36 nearshore stations. The present investigation attempts to study the time variation of the grain-size along the coast and in order to observe one-year cycle of the perpendicular profile of the beach. Teluk Lipat beach faced a huge modification compared to other beaches. The severely-eroded beaches in the study area characterized by coarse sand. Sediments from backshore and upper beach zone decreased in mean size and became poorly sorted towards surf zone area. Meanwhile, superficial sediment distribution of nearshore area revealed that silt is the most dominant component and the sediment size became coarser towards the shoreline. The results favor an alternative explanation, indicating that the river is the main source for the coastal sands, which are probably reworked by longshore currents on opposite directions apart from the river mouth resulting on coastal propagation.
\end{abstract}

Keywords: Tropical, Marine, Shoreline changes, Deposition, Erosion

\begin{abstract}
Abstrak
Pemahaman yang lebih baik berkenaan proses pantai perlu merangkumi perairan laut cetek berhampiran atau persekitaran pesisir pantai. Kertas kerja ini memberi tumpuan kepada kajian sedimentologi dan morfologi sepanjang pantai Terengganu di antara Dungun dan Kemaman. Kawasan kajian terdiri daripada lima pantai dan 36 stesen berdekatan pantai (nearshore). Kajian ini cuba untuk mengetahui perubahan saiz butiran di sepanjang pantai terhadap masa dan memerhatikan kitaran satu tahun profil serenjang pantai. Pantai Teluk Lipat mengalami pengubahsuaian yang besar berbanding pantai yang lain. Pantai yang teruk terhakis di kawasan kajian mempunyai ciri-ciri pasir yang kasar. Sedimen dari pesisir belakang dan zon atas pantai mengalami penurunan saiz min dan menjadi kurang tersusun. Sementara itu, pengedaran sedimen di kawasan cetek berdekatan pantai mendedahkan bahawa kelodak adalah yang paling
\end{abstract}


dominan dan saiz sedimen menjadi semakin kasar berhampiran kawasan berdekatan pantai. Keputusan menunjukkan bahawa sungai adalah sumber utama bagi pasir pantai, yang mungkin di bawa oleh arus susur pesisir pada arah yang bertentangan selain daripada muara sungai, menyebabkan pada pembiakan pantai.

Kata kunci: Tropika, Marin, Perubahan garis pantai, pemendapan, hakisan

(C) 2018 Penerbit UTM Press. All rights reserved

\subsection{INTRODUCTION}

A coastal area consists of the interface between land and sea. It is a highly dynamic environment with a combination of many physical processes, such as tidal inundation, sea level rise, land subsidence, and erosion-deposition. Naturally, those processes play an important role to the changes of a shoreline and coastal landscape. The dynamic equilibrium of the beach is not only interrupted by the forces of nature, but also by man-made activities. The building of constructed seawalls, breakwaters, the advancement of the shoreline artificially by land reclamation, and the removal of beach material from the coastline caused various effects to the coastal area [1]. In the past two decades the coastal areas close to the Gulf of Thailand from the nearest Malaysian East coast to the southeastern tip of Thailand coast have been progressively eroded. At present the intensity and rate of coastal erosion are continuing without any sign of slowing down especially during monsoon season [2].

The monsoon along the Terengganu coastline is governed by the Northeast Monsoon (October to March) and the Southwest Monsoon (May to September) each year [3]; [4]; [5]; [6] and [7]. The Dungun-Kemaman coast is located in Terengganu state and is known as a recreational area with a long stretch of unconsolidated quartz sandy beaches. Geographically, the coastline faces the South China Sea (SCS) and the waves impinged at the various angles on the coastline and they vary with seasons.

The coastline is relatively straight and aligned at about 315 degree [8]. During the Northeast Monsoon season, the waves approach from the northeast at an angle of 40 to 45 degrees. The width of the surf zone during this season ranges from 10 to $15 \mathrm{~m}$ [9]. Throughout the Northeast monsoon season, this area experience heavy rains, strong winds and waves, whilst relatively calm and stable conditions were observed during the non-monsoon seasons [10]. These significant weather changes are believed to influence the dynamic changes of beach morphology and sediments distribution in the East Coast of Peninsular Malaysia.

The beach zonation is divided into nearshore, foreshore and backshore; its boundaries may be translated by cyclic migration [11]. As the beach is part of the coastal regimes, this environment plays a vital role in protecting the backshore and acts as a first line of defense against the large destructive waves that normally occur during the storms [12]. Therefore, knowledge of coastal processes is necessary for the comprehensive understanding of the depositional or erosional framework of a coastline. As a matter of fact, the present study aims to: i) determine the trend of morphological changes along the beach from Dungun to Kemaman and ii) investigate the distribution of sediment characteristics at the study area.

\subsection{METHODOLOGY}

\subsection{Study area}

The coast and nearshore area of Terengganu is subjected to seasonal monsoon cycles $[13,14,15,16$, 17]. The Northeast Monsoon dominates the South China Sea (SCS) region from November to March, which results in strong northeasterly monsoon wind stress. This strong monsoon wind causes a strong south westerly current in the east coast of Peninsular Malaysia. On the other hand, the southwest monsoon dominates the SCS region from April to August. The weaker southwesterly summer monsoon wind stress results in a wind stress that drives a northward coastal current off the east coast of Peninsular Malaysia.

\subsection{Beach Profile Monitoring}

The assessment of the beach profile was carried out from February 2008 to February 2009. The coordinates of the sampling stations were marked using a global positioning system (GPS) (Table 1). Transit method was employed to survey beach profiles bi-monthly at fixed points from the backshore to a closure depth equivalent with low water level at the particular time. The shore features were simultaneously observed and documented. The analysis of the two-dimension profile data led to the calculation of beach gradients and morphology, and the estimation of lost/gained volumes of sand. 
Table 1 The coordinates of sampling beach

\begin{tabular}{lcc}
\hline \multicolumn{1}{c}{ Beach } & Latitude & Longitude \\
\hline Beach 1- Kuala Abang & $04^{\circ} 49.607^{\prime} \mathrm{N}$ & $103^{\circ} 25.022^{\prime} \mathrm{E}$ \\
Beach 2- Teluk Lipat & $04^{\circ} 45.012^{\prime} \mathrm{N}$ & $103^{\circ} 25.487^{\prime} \mathrm{E}$ \\
Beach 3- Kijal & $04^{\circ} 22.679^{\prime} \mathrm{N}$ & $103^{\circ} 27.731^{\prime} \mathrm{E}$ \\
Beach 4- Teluk Kalung & $04^{\circ} 17.010^{\prime} \mathrm{N}$ & $103^{\circ} 28.585^{\prime} \mathrm{E}$ \\
Beach 5- Teluk Mak Nik & $04^{\circ} 11.447^{\prime} \mathrm{N}$ & $103^{\circ} 26.579^{\prime} \mathrm{E}$ \\
\hline
\end{tabular}

\subsection{Sampling}

The coastal sediment samples were divided into beach and nearshore segments (Figure 1). Beach sediment samples were collected before and after the Northeast Monsoon at three different tidal zones (berm, mid-tidal and low-tidal zones) using a small shovel to scoop approximately a thickness of $5 \mathrm{~cm}$ of the surface. A total of 36 nearshore sediment samples from 12 transect lines were collected using Smith Mclntyre Grab sampler on a class A fisherman vessel. Sediment samples were air-dried in the laboratory and kept in the wrapping plastic bag before further analysis.

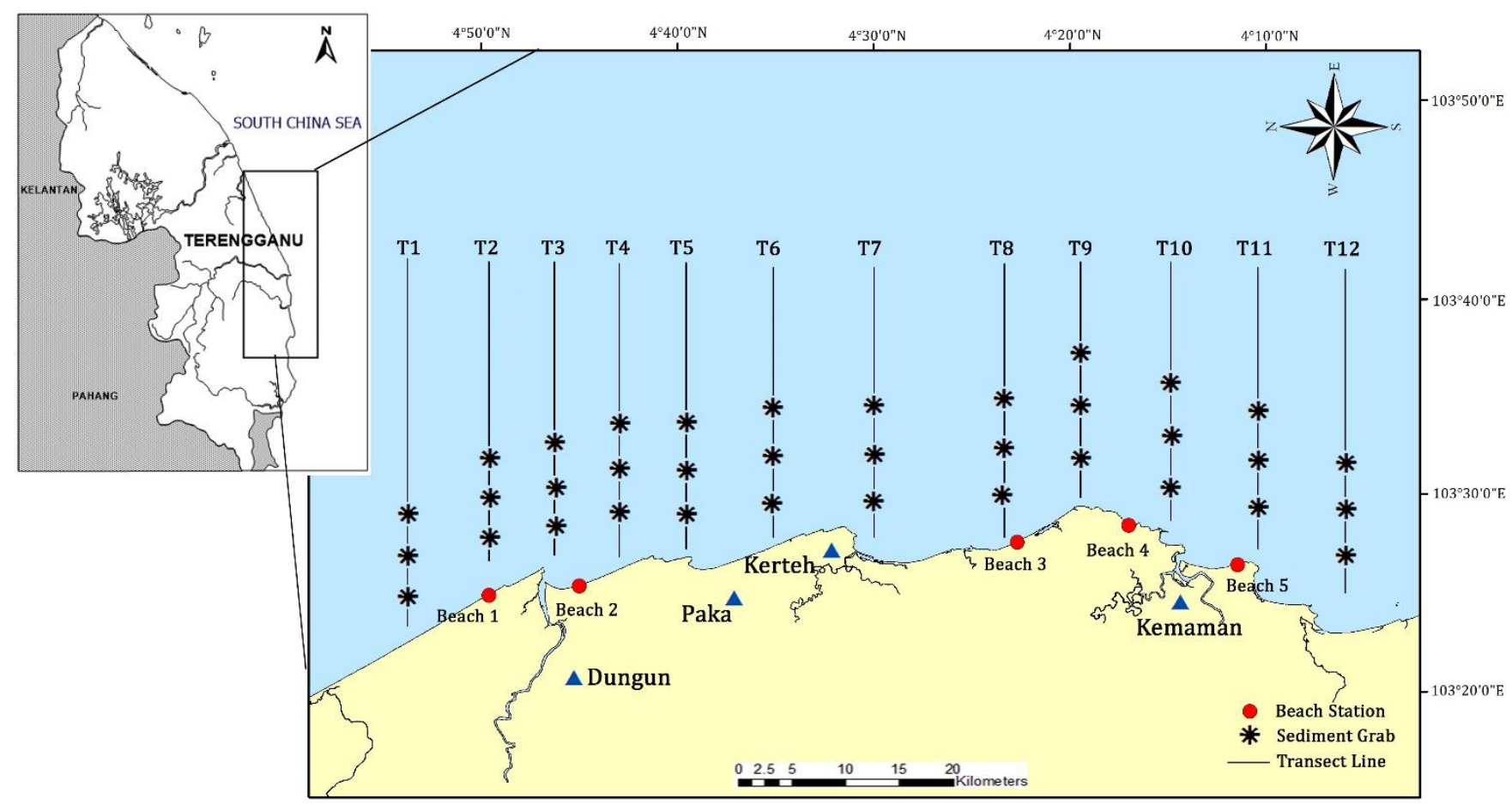

Figure 1 Map showing an overview of transects ( $\mathrm{T} 1$ - T12) and sampling sites (Beach 1 - 5) of the Dungun - Kemaman Coast

\subsection{Laboratory Analysis}

Samples of beach sediment were analyzed by dry sieving method in the laboratory using a series of 13 sieves arrange in the descending order $(4000 \mu \mathrm{m}$ to $63 \mu \mathrm{m})$. Nearshore samples contain mostly silt and clay were analyzed using laser diffraction analyzer (MALVERN Mastersizer 2000). Approximately $5 \mathrm{~g}$ of the sediment samples were used in determining particle size. Homogenized samples were treated with $10 \mathrm{ml}$ calgon solution overnight and injected into the laser diffraction analyzer. All data collected were subjected to statistical analysis using moment statistical method [18]. The mean grain size was calculated using the formula established by Folk and Ward [19]. The relative proportion of sand, silt and clay were determined using the textural triangle proposed by USDA [20].

\subsection{RESULTS AND DISCUSSION}

\subsection{Annual Beach Morphology Changes}

Beach morphology and sand volumetric changes reflected a great seasonal variation caused by wave actions. More beach erosion was observed between October and December, and increased deposition occurred from June to August (Figure 2). The effects of erosion are similar for all beaches, with sediment from the backshore and upper foreshore shifting to the lower foreshore.

The beach erosion of Terengganu's coastline caused by large waves during the Northeast Monsoon seasons is not a new issue. For the last two decades, Husain et al. [12] has noted the occurrence of beach erosion along the coastline of Kuala Setiu caused by large waves during the northeast monsoon seasons. 
Comparatively, the morphology of Teluk Lipat beach was found to be the narrowest beach among the others during the study period whilst Teluk Kalung beach was the most stable throughout the year. The narrowing process of Teluk Lipat beach is due to the influence of wave energy during the Northeast Monsoon (Feb 2008, Dec 2008 and Feb 2009). High intensity wave energy pulls fine sand away from the beach, hence, creating narrower and cobbled beaches. The lower and gentle post-monsoon phase waves are expected to carry sand onshore causing the expansion of Teluk Lipat beach. But, this process is not certainly occurred due to the development of man-made structures such as breakwaters which have modified the natural movement of the sand.
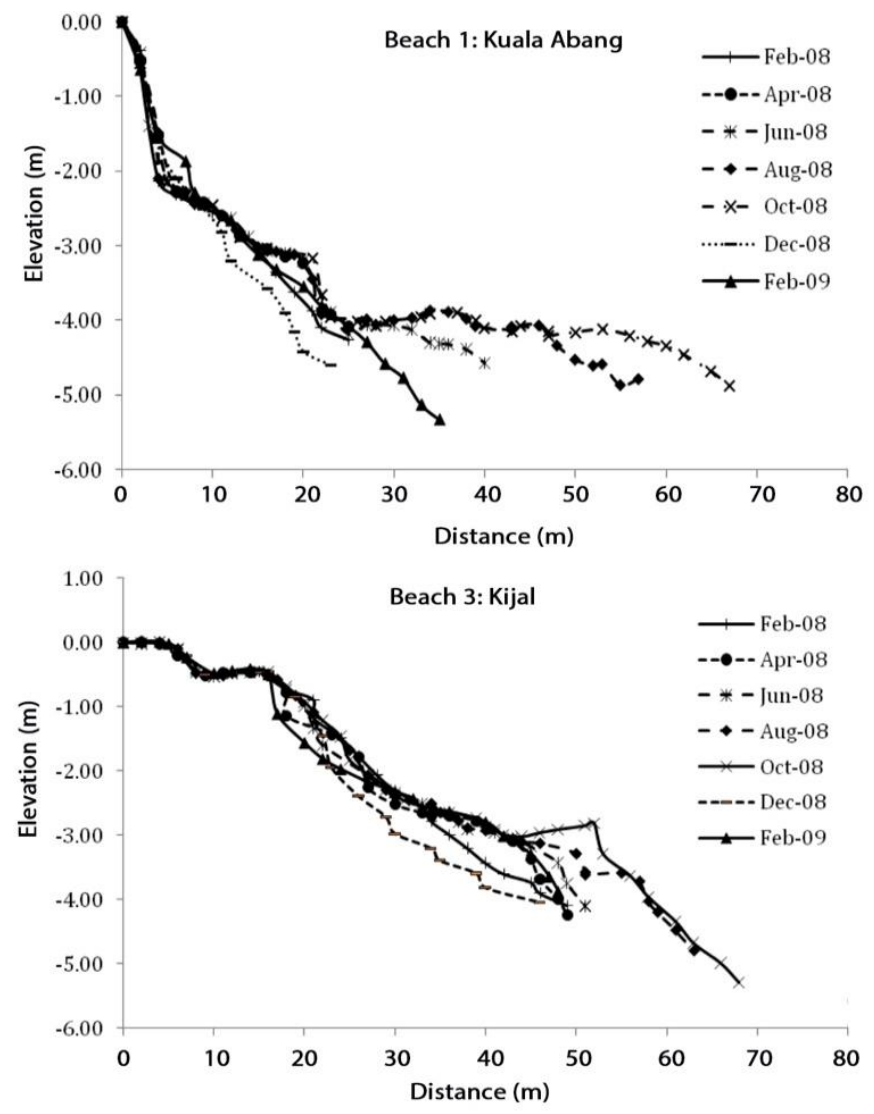

The sand that should be deposited at the beach was trapped behind these man-made structures causing continuous erosion on the Teluk Lipat beach. Morton [21] revealed that the insufficient sediment supply to the beaches is one of the contributing factors to the coastal erosion.

The stable condition of the Teluk Kalung beach is due to the sheltered condition from the effects of high energy waves during the Northeast Monsoon. In addition, the Teluk Kalung beach, located close to the Kemaman River provide this beach with sufficient which nourished this beach with a sufficient sediment supply to replace the lost sediment after the Northeast Monsoon.
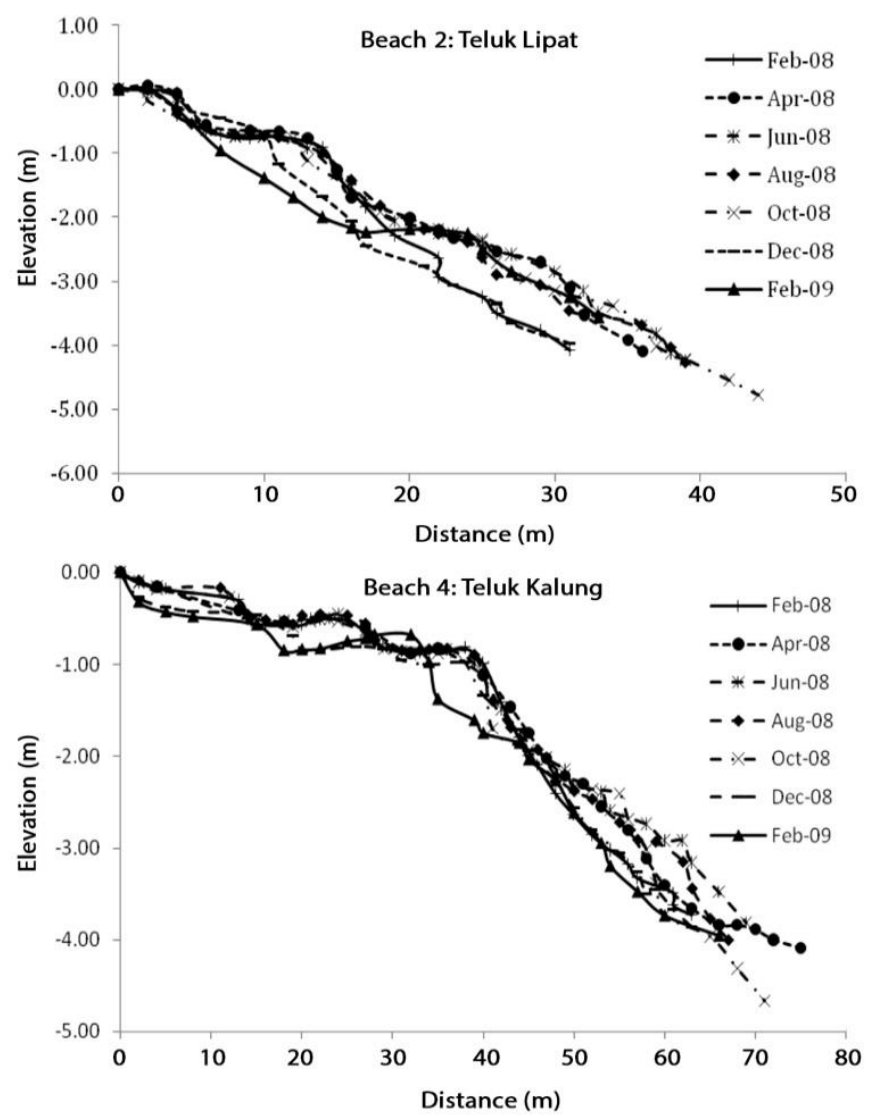

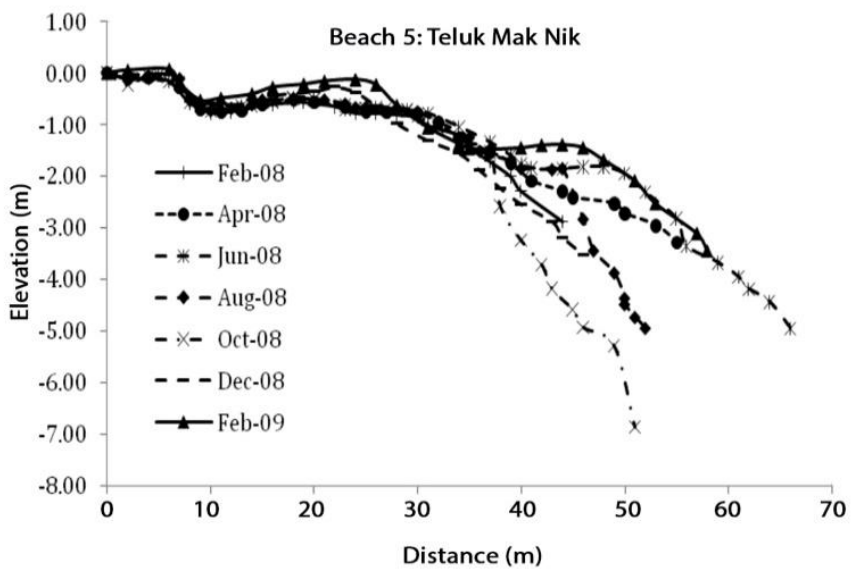

Figure 2 Morphological changes at beach stations (Kuala Abang, Teluk Lipat, Kijal, Teluk Kalung and Teluk Mak Nik) in one-year cycle 


\subsubsection{Beach Slope}

The slope of a beach is the angle formed by the intersection of the plane of the beach with the horizontal plane of the seawater surface. The size of the beach slope or degree of beach slopes by more or less, fixing the width of the beaches covered by tidal water [22]. The periodical beach slopes between stations are illustrated in Figure 3. It shows spatially inconsistent fluctuation on the average slopes. On the average, the steeper slope was observed mostly at Beach 5 whilst gentler slope degrees were found at the northern region of the study area (Beach 1). The wider beach at Beach 1 was probably due to the beach rocks present at this station. Beach 5, which also recorded higher slope value, was also located near a headland. The geologic controls could impact on wave transformation making the energy more or less powerful [23]. The wave transformation on headlands will increase longshore variation in wave direction, wave height and therefore variation in beach type. The headlands can also induce topographically controlled rips resulting in permanent beach scour [24]. This theoretical explanation proven by the steeper slope appeared at Beach 5 especially in August and October 2008. On the contrary, the gentler slope appeared at Beach 1 (beach rock) may be due to the diffraction of waves which results in smaller breaking waves behind the obstacle, and therefore reduced the water level setup [23].

\subsubsection{Beach Width}

The beach width is defined as the horizontal dimension of the beach measured at right angles to the shoreline from the line of extreme low water inland to the landward limit of a beach. It is an important parameter for measuring the 'health' of a beach. The beach width is one of the essential components of a geomorphology indicator [25]. Understanding how the beach width changes over varying timescales is vital for future shoreline management planning, i.e. planning beach nourishment, defining hazard setbacks, identifying 'hot spots' (locations of enhanced erosion) and the threat they pose from recreational activities. The cross-sectional beach widths were measured and illustrated in Figure 4. From the average beach width data, the wider beach is observed at Beach 4 whilst the narrowest beach is mainly found at Beach 1. This signify that Beach 4 is more sheltered and received less energy as the area is an embayment area.

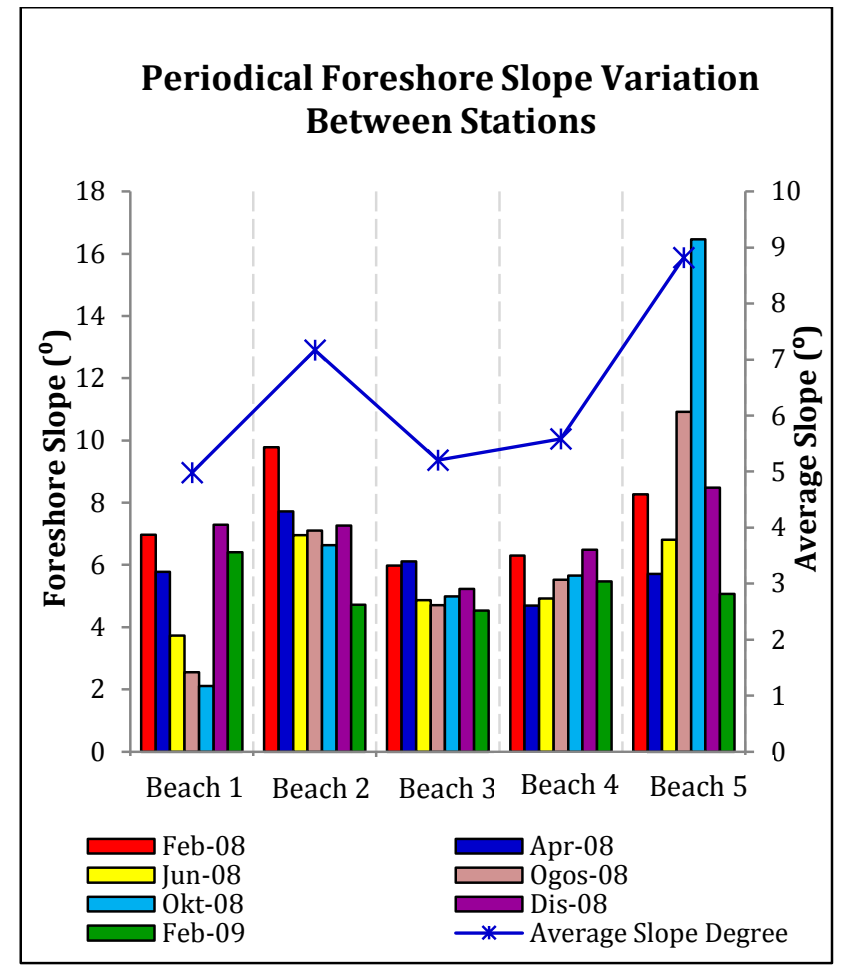

Figure 3 Periodical beach slope variation between stations

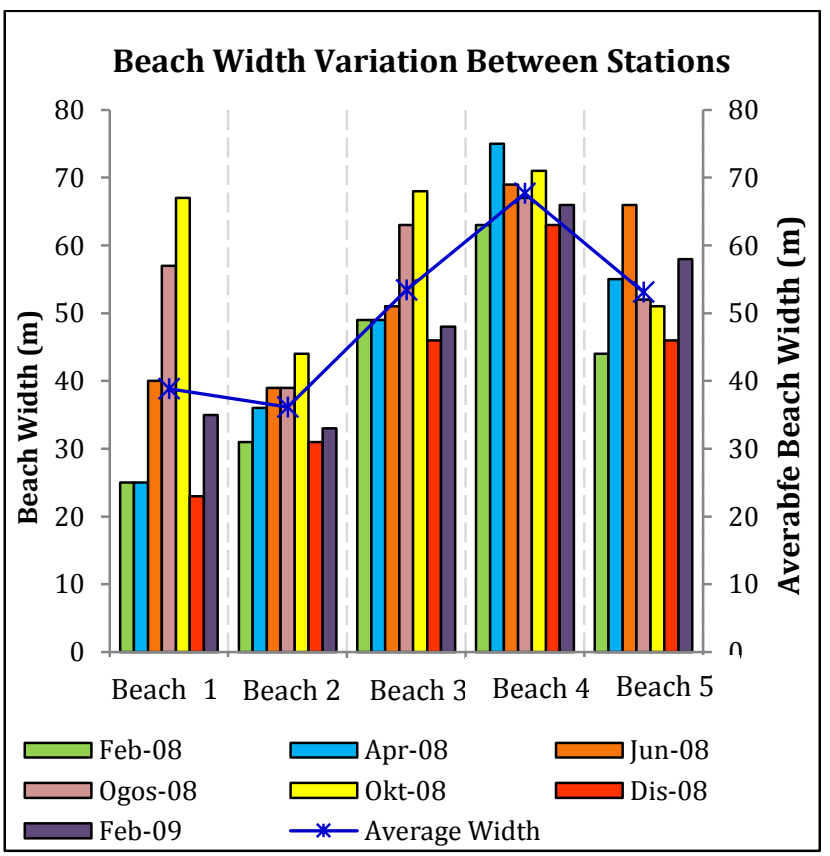

Figure 4 Temporal beach width variation between stations 


\subsection{Sediment Texture and Characteristics}

The mean size for all station shows that there is a distinct separation before and during the monsoon season (Figure 5). Beach 1, Beach 2 and Beach 3 experienced erosion during the monsoon, in contrast to Beach 4 and Beach 5 where the sand formed with slightly finer at surf zone vicinity. Beach sediment was composed of medium to finer sand, with coarser sediments during the northeast monsoon and finer sediment in the inter-monsoon season, with an average seasonal difference of 0.5 phi. Fine sand is winnowed away by breaking waves, causing the sand to be negatively skewed or coarser grained [26].
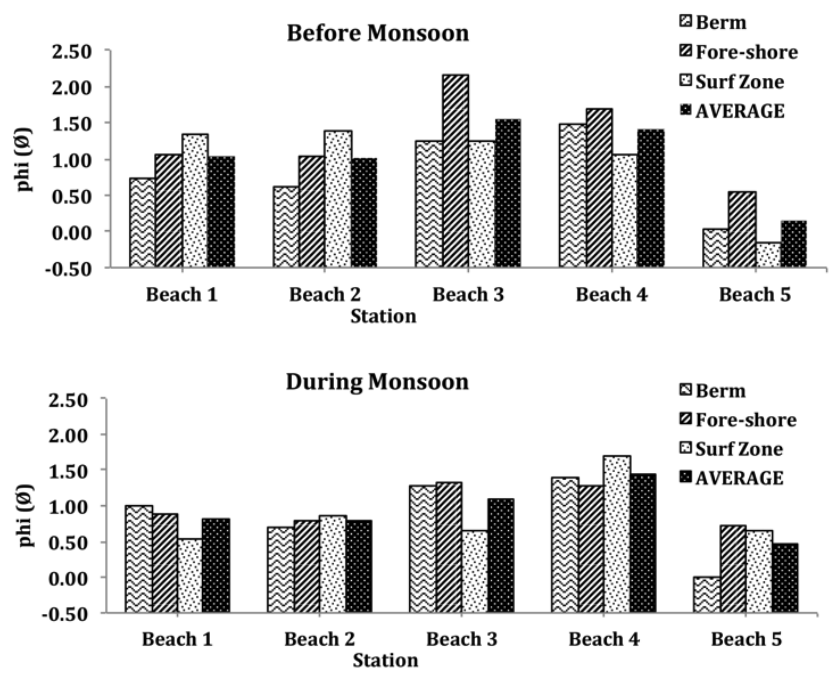

Figure 5 Mean size particles of all samples at different environment a) before and b) during monsoon

The variation in the grain-size from the different environments indicates a distinctive separation between mean size and skewness value at each beach (Figure 6a, Figure $6 \mathrm{~b}$ and Figure $6 \mathrm{c}$ ). Most of the beach comprise with very negatively skewed and suggested that the coarser grains are more dominant than the finer grains. In addition, the sorting type consists of moderately sorted and moderately well-sorted type of sediment. This study has also demonstrated that statistical grain size distribution can be used to differentiate any particular subenvironments in coastal areas. However, the combination of physical forces that acted upon the areas of study were varied due to seasonality and morphological factor.
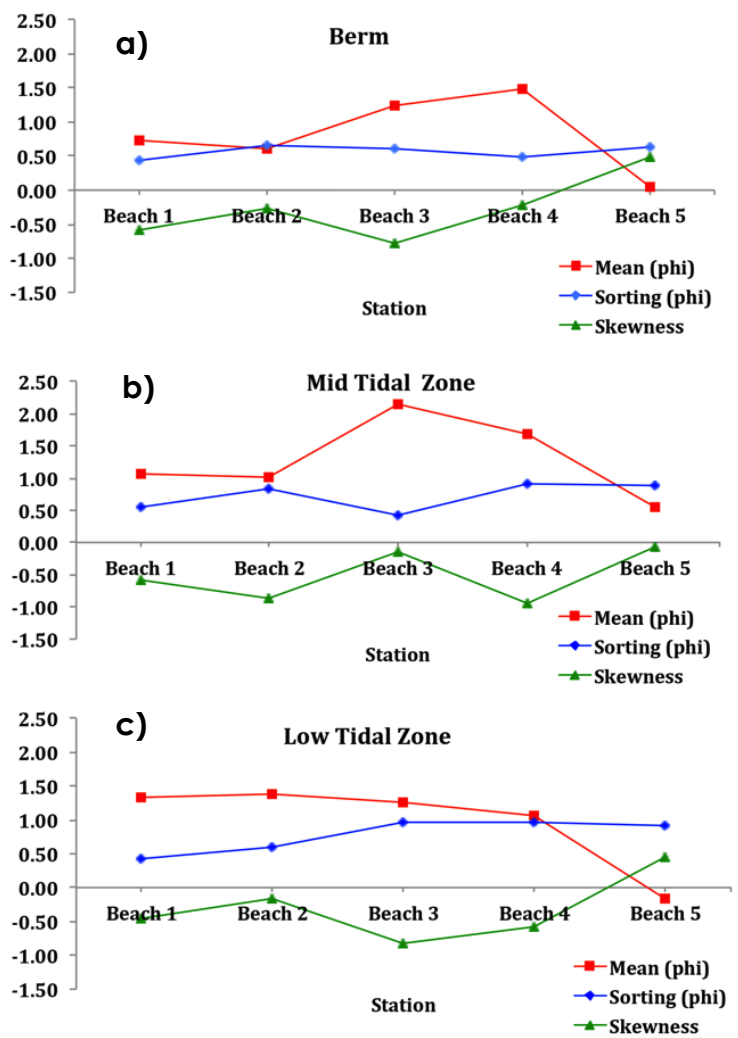

Figure 6 Statistical Parameter of a) berm, b) mid tidal and c) low tidal zone samples versus station

\subsection{Relationship between Mean Grain Sizes and Foreshore Slope}

Many observers have reported a close relationship between mean grain size and beach-face slope [27]; [28] and [29]. Finer grain area associated with lower slope angles and that erosion produces higher slopes than deposition [30]. Shepard [31] provided the average relation between slope and grain size. This relation has been plotted on Figure $7(a)$ and $7(b)$ for comparison with beach-face slopes along the beaches studied. Slopes were measured perpendicular to the water line based on the reference point of all profile stations. Mid-tide (MT) and low-tide (LT) samples were selected for this relationship, as both samples were collected at the foreshore zone. The wide scattered data around the average trend falls into a very wide variety. This may be as consequences of the mixed nature of the grain-size populations.

Fine sand and medium sand produce slopes that are optimum for their size groups whilst the coarse sand and very coarse sand fractions produce a wider variety of slopes that are consistently below the optimum gradient. This elucidates that the fine and medium sand sediment are highly mobile and can readily adopt a slope that is in equilibrium with the prevailing hydrodynamic conditions. The steeper slopes, mostly adopted by the coarse sand fraction on the foreshore suggest that it is not in stable 
equilibrium with respect to wave conditions. This suggests a response to erosional conditions; "combing-down" of the profile by storm swashbackwash [27]. The highest slope angles were observed on coarse sand fraction where the foreshore degrees were $10.92^{\circ}$ to $16.43^{\circ}$ found both at mid-tide and low-tide areas.

In an attempt to prove the correlation between the slope degrees and mean grain-size parameters, the Pearson's Correlation Coefficient was used with the acronym ' $r$ ' in the Microsoft Excel tools. The coefficients of determination (R2) for the regression equation in mid-tide and low-tide data are 0.092 and 0.079 respectively, which indicates that the relationship plotted are $9.2 \%$ and $7.9 \%$ of the variation in the data (Figure $7(a)$ and $7(b)$. Nevertheless, the relationship strength clustered from the Pearson-correlation coefficient in mid-tide $(r=$ 0.303 ) and low-tide ( $r=0.282)$ shows that both areas were grouped as definite but weak relation. This signifies that not all steep slopes at the study area are really close related to the coarse grains and vice versa. It might influenced by the physical factors and the geographical condition of each beach station.

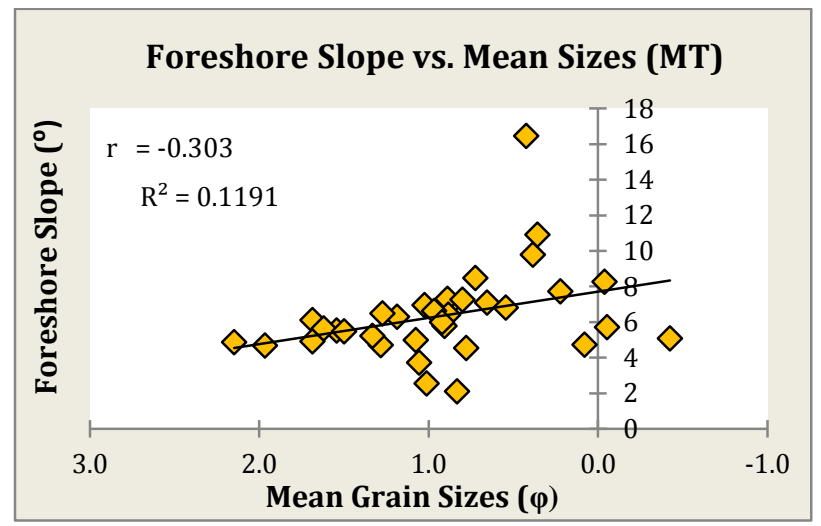

Figure 7 (a) The relationship between mean grain size (MT) and beach slope. A.R. = the average relationship of Shepard (1963)

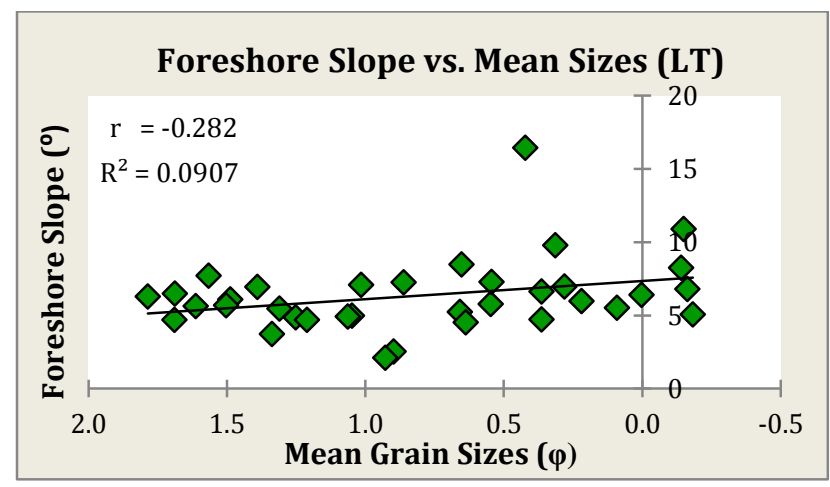

Figure 7 (b) The relationship between mean grain size (LT) and beach slope. A.R. = the average relationship of Shepard (1963)

\subsection{Nearshore Sediment}

Nearshore area includes the region that extend from the low tide line out across the surf zone and includes the sand bars that are common in the coastal environment. The percentage of sand, silt and clay of surface sediment were varied in the nearshore area (Table 2). The nearshore surface sediments in the study area are dominated by silty loam grain type (Figure 8). Most of the sediments, accumulated as silty loam and some of them were distributed as a silty clay loam, silt and loam. Stations 1 - 4, 7, 19, 21, 24 27 and 29 consisted of sand type sediments. Thus, we suppose that the accumulated sediment in the nearshore area are persistance to the high energy of water.

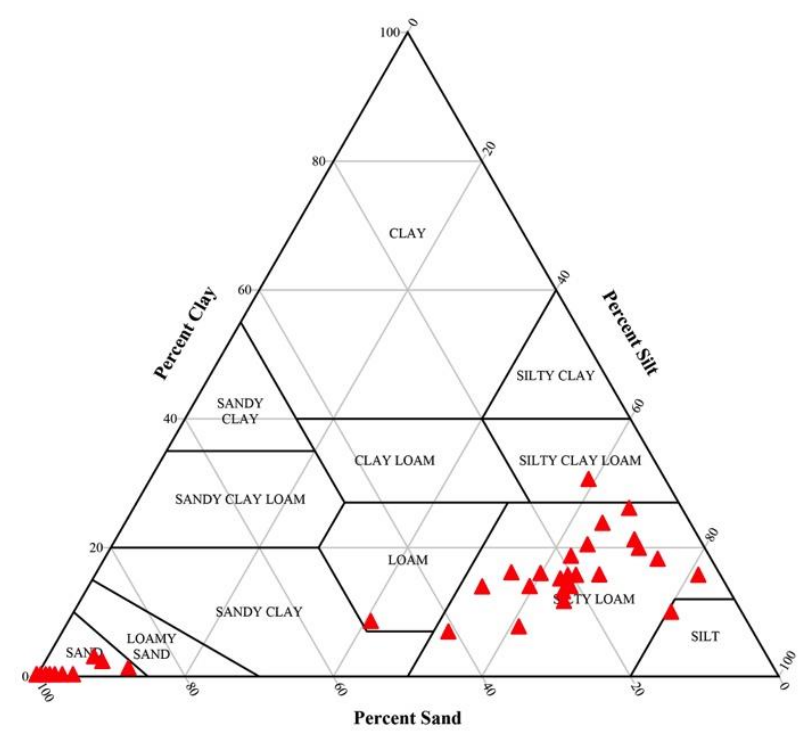

Figure 8 Sediment distribution for samples that analyze using laser diffractometer

The distribution of silt and sand in the nearshore surface sediment from Dungun to Kemaman area is relatively assorted (Figure 9). Generally, the depth of nearshore area increases extending seaward. The surface sediments are predominantly sand (mean grain size $<2.0$ phi) in the area located close to the shore due to the shallow water depth. The seaward area with deeper water, surface sediment are more prevalent with silty type of sediments. The finest and well-sorted sediments are frequently on the seaward side of the bar crest where wave energy is at the highest, and the coarsest and poorly-sorted sediment is in the trough which receives the lowest impact of wave energy [32]. Thus, we suppose that the distribution of sediment particles in the study area are relatively linked to the water depth and coastal current dynamics. 
Table 2 Percentage of sand, silt, clay and sediment texture at nearshore area

\begin{tabular}{|c|c|c|c|c|c|c|c|c|c|}
\hline Station & Sand & Silt & Clay & Texture & Station & Sand & Silt & Clay & Texture \\
\hline 1 & 100 & - & - & Sand & 19 & 87.10 & 11.86 & 1.04 & Sand \\
\hline 2 & 99.44 & 0.56 & - & Sand & 20 & 21.24 & 65.05 & 13.69 & \\
\hline 3 & 98.78 & 1.22 & - & Sand & 21 & 90.86 & 6.34 & 2.80 & Sand \\
\hline 4 & 96.54 & 1.69 & - & Sand & 22 & 50.84 & 40.89 & 8.26 & Loam \\
\hline 5 & 18.81 & 62.83 & 18.39 & Silty Loam & 23 & 19.61 & 64.93 & 15.43 & Silty Loam \\
\hline 6 & 10.48 & 58.53 & 30.31 & $\begin{array}{l}\text { Silty Clay } \\
\text { Loam }\end{array}$ & 24 & 100 & - & - & Sand \\
\hline 7 & 98.23 & 1.77 & - & Sand & 25 & 100 & - & - & Sand \\
\hline 8 & 15.69 & 64.98 & 20.17 & Silty Loam & 26 & 90.12 & 7.83 & 2.05 & Sand \\
\hline 9 & 7.36 & 74.66 & 17.92 & Silty Loam & 27 & 95.10 & 4.90 & - & Sand \\
\hline 10 & 26.73 & 55.87 & 13.68 & Silty Loam & 28 & 8.98 & 70.05 & 20.94 & Silty Loam \\
\hline 11 & 22.00 & 63.12 & 14.87 & Silty Loam & 29 & 97.55 & 2.45 & - & Sand \\
\hline 12 & 9.66 & 80.63 & 9.71 & Silty Loam & 30 & 7.25 & 66.94 & 25.83 & Silty Loam \\
\hline 13 & 33.15 & 53.23 & 13.63 & Silty Loam & 31 & 23.26 & 65.36 & 11.37 & Silty Loam \\
\hline 14 & 22.62 & 64.51 & 12.89 & Silty Loam & 32 & 16.44 & 63.50 & 15.49 & Silty Loam \\
\hline 15 & 3.12 & 81.44 & 15.44 & Silt & 33 & 28.12 & 56.05 & 15.82 & Silty Loam \\
\hline 16 & 31.32 & 61.25 & 7.42 & Silty Loam & 34 & 24.24 & 60.07 & 15.71 & Silty Loam \\
\hline 17 & 20.73 & 63.90 & 15.39 & Silty Loam & 35 & 41.20 & 50.84 & 6.64 & Silty Loam \\
\hline 18 & 9.05 & 69.96 & 19.62 & Silty Loam & 36 & 12.00 & 64.53 & 23.51 & Silty Loam \\
\hline
\end{tabular}




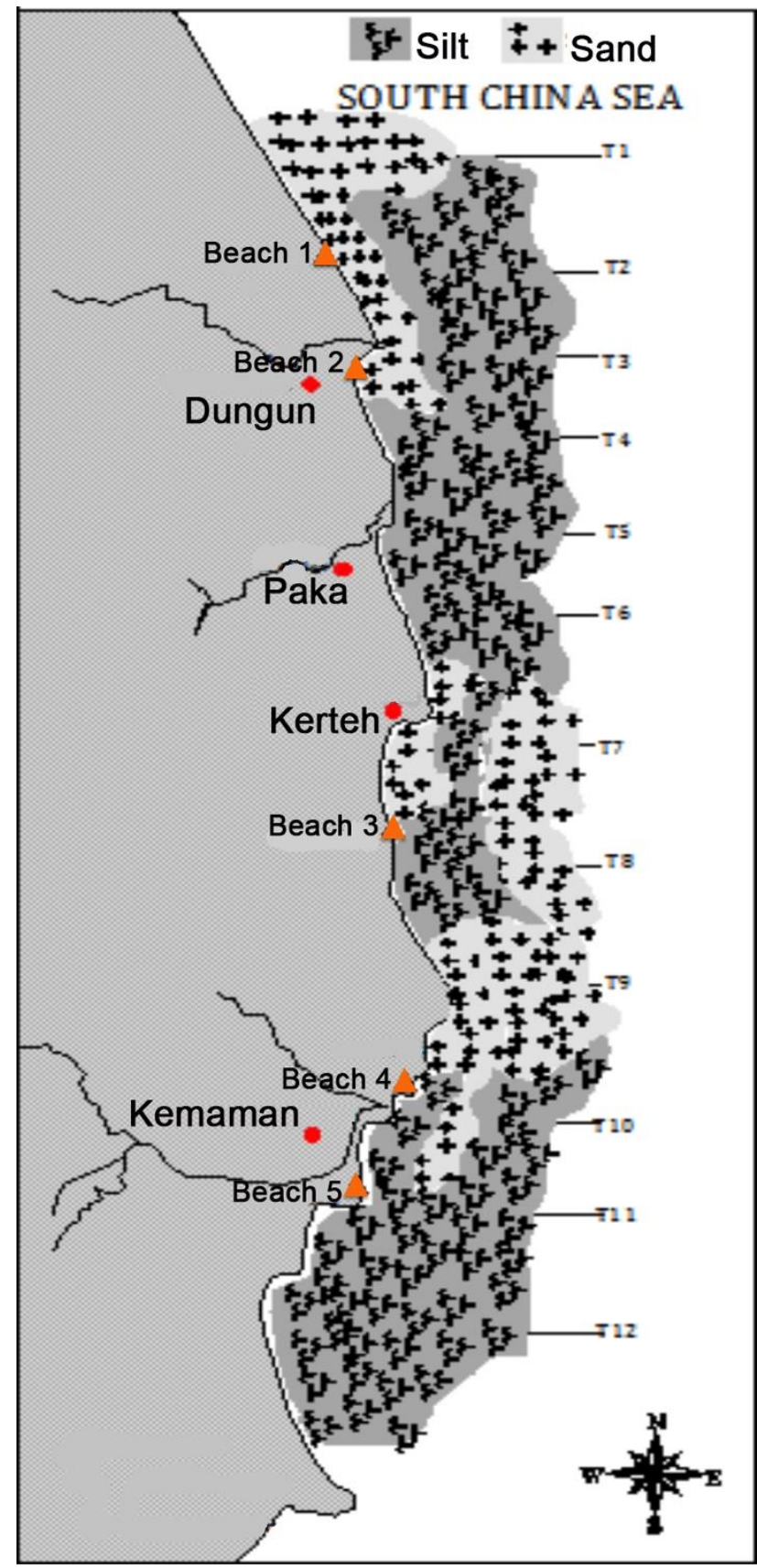

Figure 9 Superficial sediment distribution of Dungun Kemaman nearshore area

\subsection{CONCLUSSION}

The information regarding the littoral process and its surrounding environment is very useful for a better understanding towards managing the coastal area effectively. Based on the beach profile monitoring, Beach 2 (Teluk Lipat) experienced a larger change compared to the other stations. An excess of coarser grain indicates the severity-eroded beaches at the study area. The grain size analysis reveals that the mean size of the sediments from both the backshore and upper beach zone decreased and tend to be coarse grain and poorly sorted. On the other hand, superficial sediment distribution of nearshore area revealed that silt was the most dominant and the sediment size became coarser towards the beach area. The distribution of nearshore sediment of Dungun-Kemaman is attributed to the factor of water depth. Shallow water and shoreward area consist predominantly of sand, while, the deeper and seaward areas are dominated by silt type of sediment.

\section{Acknowledgement}

This project was funded by Ministry of Science, Technology and Innovation (MOSTI) under the Science Fund Grant (04-01-12-SF0039). Authors duly acknowledge their respective institute heads for the facilities and encouragement. The authors also wish to express their gratitude to the Mr. Mohd Azam Yaacob and technical staff of Institute of Oceanography and Environment (INOS) during samples collection and analysis.

\section{References}

[1] Bird, E. C. F., and Ongkosongo, O. S. R. 1980 Environmental Changes on the Coasts of Indonesia. The United Nations University: United Nations University Press.

[2] Prinya, N. 1996. Coastal Erosion in the Gulf of Thailand. Geol. J. 38(3): 283-300.

[3] Akhir, M. F. M., Zakaria, N. Z., and Tangang, F. 2014. Intermonsoon Variation of Physical Characteristics and Current Circulation along the East Coast of Peninsular Malaysia. Int. J. Oceanogr. 2014: 1-9.

[4] Akhir, M. F. 2015. Review of Current Circulation Studies in the Southern South China Sea. J. Sustain. Sci. Manage. 9(2): 21-30.

[5] Rosnan, Y., and Ariffin, E. H. 2010. Effects on Sedimentology and Beach Morphology on Tourism at Terengganu Beach, Malaysia. In International Annual Symposium Universiti Malaysia Terengganu. 553-557. Kuala Terengganu: Universiti Malaysia Terengganu.

[6] Rosnan, Y., and Husain, M. L. 2005. The Relationship of Sediment Texture with Coastal Environments along the Kuala Terengganu Coast, Malaysia. Environ. Geol. 48: 639643.

[7] Sultan, K., and Shazili, N. A. M. 2009. Distribution and Geochemical Baselines of Major, Minor and Trace Elements in Tropical Topsoils of the Terengganu River basin, Malaysia. J. Geochem. Explor. 103(2-3): 57-68.

[8] Rosnan, Y., Othman, M. A., Hussain, M. L., and Yaacob, M. A. M. 2005. A Study of the Sediments Characteristics and Net Shore-drift Direction at the Kuala Besar and Cahaya Bulan Beach, Kelantan (Malaysia). Ultra Sci. 17: 41-56.

[9] Husain, M.L., Rosnan, Y., Ejiria, S., Shazili, N. A. M., and Kassim, K. K. Y. 1998. Deducing Sediment Transport Direction and the Relative Importance of Rivers on a Tropical Microtidal Beach using the "McLaren Model". Environ. Geol. 34: 128-134.

[10] Rosnan, Y., Kamaruzzaman, Y., Husain, M. L., Suffian, I. and Subarjo, M. 2002. The Effect of Monsoon to the Beach Morphodynamic and Sediment Distribution along Kuala Terengganu Coastline. Ultra Scientist Int. J. Phy. Sci. 14: 367-384.

[11] Schwartz, M. 1982. (Ed.). The Encyclopedia of Beaches and Coastal Environments. Hutchinson Ross: Stroudsburg, 
[12] Husain, M. L., Khairul A'mali, I., and Rosnan, Y. 1995. Shortterm Impact of Beach Fest on the Topography, Vegetation Coverage and Sediment Distribution of the Mengabang Telipot Beach, Terengganu. Pertanika J. Sci. \& Tech. 3: 325-336.

[13] Wyrtki, K. 1961. Scientific Results of Marine Investigations of the South China Sea and the Gulf of Thailand 1959-1961. Naga Report 2.

[14] Mao, Q. W., Shi, P., and Qi, Y. Q. 1999. Sea Surface Dynamic Topography and Geostrophic Current Over the South China Sea from Geosat Altimeter Observation. Acta Oceanologica Sinica. 21(1): 11-16.

[15] Hu, J., Kawamura, H., Hong, H., and Qi, Y. 2000. A Review on the Currents in the South China Sea: Seasonal Circulation, South China Sea Warm Current and Kuroshio Intrusion. J. Oceanogr. 56: 607-624.

[16] Yen, Y. L., Billa, L., and Singh, A. 2015. Effect of Climate Change on Seasonal Monsoon in Asia and Its Impact on the Variability of Monsoon Rainfall in Southeast Asia. Geosci. Frontiers. 6(6): 817-823.

[17] Daryabor, F., Ooi, S. H., Samah, A. A., and Akbari, A. 2016. Dynamics of the Water Circulations in the Southern South China Sea and Its Seasonal Transports. PLOS ONE. 11 (7): e0158415.

[18] Friedman, G. M., and Johnson, K. G. 1982. Exercises in Sedimentology. Wiley: NewYork.

[19] Folk, R. L., and Ward, W. C. 1957. Brazos River Bar: A study in the Significance of Grain Size Parameters. J Sedimentol Petrol. 27: 3-26.

[20] U.S. Department of Agriculture (USDA). 1987. Agricultural Resources: Cropland, Water and Conservation Situation and Outlook Report. AR-Econ. Res. Serv. Washington, D.C.

[21] Morton, R. A. 2003. An Overview of Coastal Land Loss: with Emphasis on the Southeastern United States, U.S. Geological Survey, Open File Report 03-337.
[22] Zinn, D. J. 1969. An Inclinometer for Measuring Beach Slopes. Mar. Biol. 2: 132-134.

[23] Tanya, S. 2005. Physical Characteristics of Perth Beaches, Western Australia. Unpublished Master's Thesis. University of Western Australia, Australia.

[24] Castelle, B., Scott, T., Brander, R. W., McCarroll, R. J. 2016. Rip Current Types, Circulation and Hazard. Earth Sci. Rev. 163: 1-21.

[25] Taggart, B. E., and Schwartz, M. C. 1988. Net Shore-drift Direction Determination: A Systematic Approach. J. Shoreline Manage. 3: 285-309.

[26] Mason, C. C., and Folk, R. L. 1958. Differentiation of Beach, Dune and Eolian Flat Environments by Size Analysis, Mustang Island, Texas. J. Sed. Petrol. 28: 211-226.

[27] Kirk, R. M. 1969. Beach Morphology and Sediments of the Canterbury Bight. Unpublished master's thesis. University of Canterbury.

[28] Rosnan, Y., and Mohd-Nasir, S. 1991. Beach and Nearshore Sediment Distribution of Kuala Terengganu. Paper presented at the International Joint IEM/ICE Conference on Coastal Engineering in National Development. Shangri-La Hotel, Kuala Lumpur.

[29] Rosnan, Y., Shazili, N. A. M., and Hazamri, H. 2002. Study of Sediment Characteristics and Beach Profile at Hatchery Complex, Tanjung Demong and Bukit Keluang Coast. Ultra Sci. 15(1): 33-48.

[30] Reis, A. H., and Gama, C. 2010. Sand Size Versus Beachface Slope - An Explanation Based on the Constructal Law. Geomorphol. 114: 276-283.

[31] Shepard, F. P. 1963. Submarine Geology. 2nd Edition. New York: Harper and Row, p. 557.

[32] Richard, D. Jr., and F.G. Duncan. 2004. Beach and Coasts. Blackwell Science. 